\title{
Impact of climate variation and change on Mid-Atlantic Region hydrology and water resources
}

\author{
Rob N eff ${ }^{1, *}$, Heejun Chang ${ }^{1}$, C. G regory Knight ${ }^{1}$, Raymond G . Najjar ${ }^{1}$, \\ Brent Yarnal $^{1}$, Henry A. Walker ${ }^{2}$
}

${ }^{1}$ Center for Integrated Regional Assessment, The Pennsylvania State University, University Park, Pennsylvania 16802, USA
${ }^{2}$ A tlantic Ecology Division, National Health and Environmental Effects Research Laboratory,
US Environmental Protection Agency, 27 Tarzwell Drive, Narragansett, Rhode Island 02882, USA

\begin{abstract}
The sensitivity of hydrology and water resources to climate variation and climate change is assessed for the Mid-Atlantic Region (MAR) of the United States. Observed streamflow, groundwater, and water-quality data are shown to vary in association with climate variation. Projections of future streamflow, groundwater, and water quality are made using models determined from these associations and are applied to 2 transient general circulation model (GCM) scenarios. Regional streamflow increases in one scenario, but decreases in the other; both scenarios result in changes in the seasonality of peak flows. Response of groundwater to climate change depends on the GCM scenario used. Canadian Climate Center (CCC) scenarios suggest recharge will occur earlier in the year, and that seasonal fluctuations in groundwater levels will be less extreme. Hadley Center scenarios suggest recharge will occur earlier in the medium term, but later in the long term, with seasonal fluctuations in general being more extreme. Both scenarios show that nutrient loads can be expected to increase in winter and spring because of the expected increase in streamflow. Projected decreases in streamflow and associated nutrient fluxes in J uly and August could ameliorate problems associated with estuarine stratification and eutrophication in late summer. These projections demonstrate that future hydrology and water resources will be influenced by climate change, but that uncertainty in accurately projecting that influence will continue until model scenarios improve.
\end{abstract}

KEY WORDS: Climate impact assessment - Climate variation · Climate change $\cdot$ Hydrology $\cdot$ Water resources · Mid-Atlantic Region · Climate models

\section{INTRODUCTION}

The Mid-Atlantic Region (MAR), which includes all of Pennsylvania, Maryland, Delaware, Virginia, West Virginia, Washington, DC, and parts of New York, New J ersey, and North Carolina (Fig. 1), has abundant freshwater resources, on average. The mean annual rainfall total is approximately $1009 \mathrm{~mm}$; annual rainfall has ranged from 647 to $1288 \mathrm{~mm}$ over the historical record. Rainfall is distributed somewhat evenly throughout the year, which suggests that there gener-

*E-mail: neff@essc.psu.edu ally might be ample quantities of water available to use in all seasons. Nevertheless, streamflow is reduced in late summer and early fall largely because of evapotranspiration during the growing season. Water resources are used for a variety of purposes including power generation, public and private water supply, industry, agriculture, waste discharges from an assortment of point and non-point sources, and for support of diverse and valued aquatic habitats. Climate variation has many effects on competing needs for finite water resources. Water and watershed management concerns include measures to conserve water supply during periods of drought, to minimize adverse impacts of 
periodic flooding, and to protect and restore the quality of the region's surface and groundwater resources.

Climate change projections from general circulation models (GCMs) for regions the size of the MAR are highly uncertain. Still, there are a number of practical planning activities that could help mitigate adverse consequences of future shifts in hydrologic variability (Lins \& Stakhiv 1998), in demand for water resources, and in changes in sources of pollution to freshwater and coastal estuaries and bays.

The goal of this research is to characterize the historical relationships between MAR precipitation and freshwater hydrology and to illustrate possible changes in regional streamflow, groundwater, and water quality resulting from climate change in the 21st century. In Sections 3 and 4, we use the Susquehanna River Basin (SRB; Fig. 1) to meet this goal for streamflow and water quality, and northwest Pennsylvania to

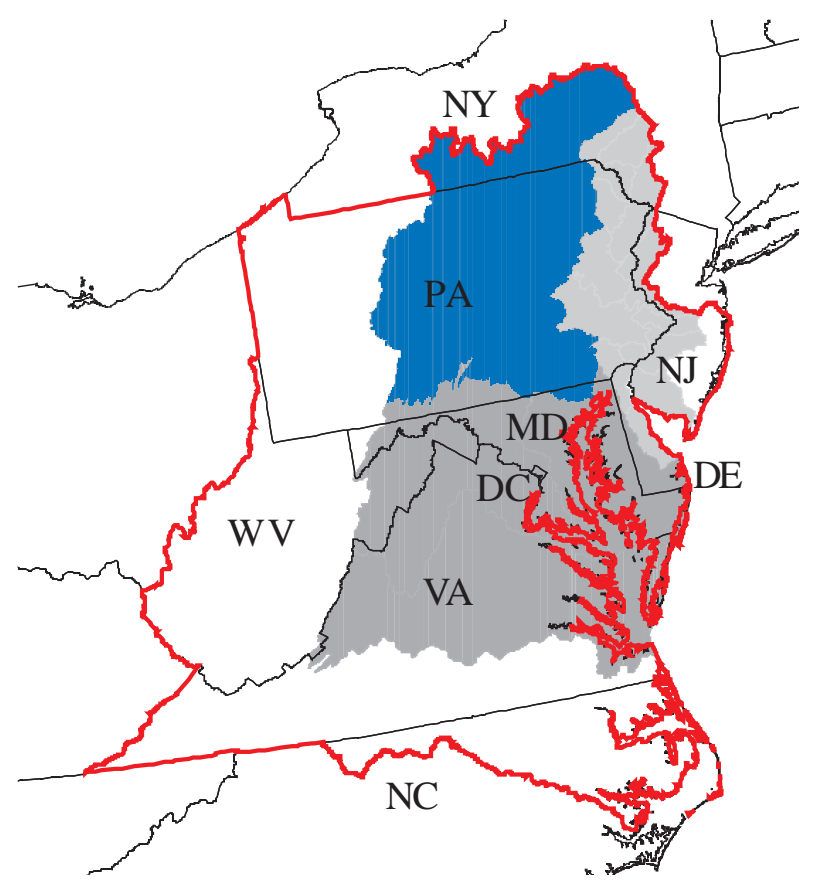

Boundaries of the Mid-Atlantic Region

State Boundaries

Susquehanna River Basin

Chesapeake River Basin (Includes the SRB)

Delaware River Basin

Fig. 1. Boundaries of the Mid-Atlantic Region, and sub-basins of the Chesapeake River Basin. First-year activities concentrated on these sub-basins; streamflow and water-quality results for the Susquehanna River Basin (SRB) are presented in this paper meet this goal for groundwater. Similar hydroclimatic studies have been conducted for 2 other MAR basinsthe Delaware River (M cCabe \& Ayers 1989, Ayers et al. 1994) and Potomac River (Steiner et al. 1997). We have conducted updated analyses for these 2 watersheds but do not present the results here. The findings for these basins support our results for the SRB. Before presenting results and discussing their implications (Section 5), we review freshwater uses, demands, and stresses in the MAR (Section 2).

\section{FRESH WATER USE}

Water use is commonly characterized in terms of groundwater withdrawals and in-stream and offstream water uses. In the MAR, however, the dominance of forests and agricultural lands means that evapotranspiration from these land-cover types accounts for the greatest water consumption. Approximately two-thirds of all precipitation returns to the atmosphere via evapotranspiration. The remaining one-third of precipitation moves as groundwater or surface water to streams, where both flows provide a valuable resource for human use.

Freshwater resources and withdrawals can be divided between surface water (lakes, reservoirs, and streams) and groundwater (wells). In 1995, approximately $90 \%$ of all M AR withdrawals were from surface water and $10 \%$ were from groundwater (Table 1 ). Delaware and Maryland used proportionally more groundwater than other Mid-A tlantic states (15 and $17 \%$ of their withdrawals, respectively). In contrast, West Virginia used much less groundwater than other political units in the region (3\% of total withdrawals) and therefore relied heavily on surface water.

Pennsylvania used more freshwater in 1995 than any state in the MAR-one-third of total regional withdrawals. This large quantity resulted from a combination of moderate per capita water use and the largest population in the region. West Virginia had by far the largest per capita water use, which ranged from roughly 2.5 to nearly 9 times that of the other states. To achieve these large withdrawals, West Virginia's demand for water includes large withdrawals by industry and thermoelectric production that are disproportionate with its population, though much of the withdrawals by thermoelectric production are returned to the watershed rather than consumed (Table 2).

Three categories dominated 1995 freshwater use in the region (Table 2): thermoelectric power generation (60\% of all withdrawals), public supply $(20 \%)$, and industry (14\%). Domestic supplies used only $2 \%$ of the freshwater supply, while all other uses were smaller. 
Table 1. Per capita water use and total freshwater withdrawals in the MAR by source type, 1995. All values in millions of gallons per day, except for per capita water use (gallons per day) and percentage tabulations. N ote that these values are calculated from United States Geological Survey county data for the MAR as defined by Fisher et al. (2000) and do not correspond to the M AR of Solley et al. (1998). 'Rest of Region' refers to Washington, DC, and the relatively few New York and North Carolina counties in the MAR; they are combined and treated as a residual here

\begin{tabular}{|c|c|c|c|c|c|c|c|}
\hline State & $\begin{array}{l}\text { Per capita } \\
\text { water use }\end{array}$ & $\begin{array}{l}\text { Ground- } \\
\text { water }\end{array}$ & $\begin{array}{l}\% \text { groundwater } \\
\text { of total }\end{array}$ & $\begin{array}{l}\text { Surface } \\
\text { water }\end{array}$ & $\begin{array}{c}\% \text { surface water } \\
\text { of total }\end{array}$ & $\begin{array}{c}\text { Total freshwater } \\
\text { withdrawals }\end{array}$ & $\begin{array}{l}\% \text { contribution to } \\
\text { total withdrawals }\end{array}$ \\
\hline Delaware & 1050 & 110 & 15 & 642 & 85 & 752 & 3 \\
\hline Maryland & 289 & 246 & 17 & 1210 & 83 & 1456 & 5 \\
\hline Pennsylvania & 802 & 860 & 9 & 8820 & 91 & 9680 & 33 \\
\hline Virginia & 826 & 358 & 7 & 5110 & 93 & 5468 & 19 \\
\hline West Virginia & 2530 & 146 & 3 & 4470 & 97 & 4616 & 16 \\
\hline Rest of region & - & 1130 & 15 & 6426 & 85 & 7556 & 26 \\
\hline Total & - & 2850 & 10 & 26678 & 90 & 29528 & - \\
\hline
\end{tabular}

Table 2. Total freshwater withdrawals by water-use category and state, 1995. Units and data source as in Table 1

\begin{tabular}{|c|c|c|c|c|c|c|c|c|c|c|}
\hline State & $\begin{array}{l}\text { Public } \\
\text { supply }\end{array}$ & Domestic & $\begin{array}{c}\text { Commer- } \\
\text { cial }\end{array}$ & $\begin{array}{l}\text { Irriga- } \\
\text { tion }\end{array}$ & $\begin{array}{l}\text { Live- } \\
\text { stock }\end{array}$ & Industry & Mining & $\begin{array}{l}\text { Thermo- } \\
\text { electric }\end{array}$ & Total & $\begin{array}{c}\% \text { total } \\
\text { MAR }\end{array}$ \\
\hline Delaware & 89 & 12 & 3 & 48 & 4 & 61 & 0 & 534 & 752 & 3 \\
\hline Maryland & 834 & 73 & 24 & 62 & 35 & 65 & 5 & 360 & 1460 & 5 \\
\hline Pennsylvania & 1550 & 181 & 30 & 16 & 55 & 1680 & 252 & 5920 & 9680 & 33 \\
\hline Virginia & 786 & 125 & 41 & 30 & 36 & 516 & 39 & 3890 & 5470 & 19 \\
\hline West Virginia & 176 & 41 & 46 & 0 & 18 & 1320 & 11 & 3010 & 4620 & 16 \\
\hline Rest of region & 2309 & 249 & 74 & 358 & 15 & 357 & 132 & 4012 & 7496 & 25 \\
\hline Total & 5744 & 681 & 218 & 514 & 163 & 3999 & 439 & 17726 & 29484 & - \\
\hline$\%$ sector total & 20 & 2 & 1 & 2 & 1 & 14 & 2 & 60 & - & - \\
\hline
\end{tabular}

Of special interest is water for irrigation, which was less than $1 \%$ of the total freshwater use. Thus, unlike many other areas in the United States, agriculture is not an important user of water in the MAR.

Despite the relatively small proportion that groundwater contributes to overall regional water use, wells are important to domestic water supplies. Of the region's domestic supply, $24 \%$ comes from privately owned wells. In the SRB, 34\% of all households are self-supplied. Nationally, the MAR ranks second only to the southeastern United States in self-supplied domestic water use, while Pennsylvania and North Carolina rank third and fourth, respectively, among the 50 states in the proportion of the population depending on privately owned wells (Solley et al. 1998).

In summary, the MAR relies upon dependable supplies of both surface and sub-surface freshwater. Because of the high average precipitation totals, supply currently meets demand in most instances (Solly et al. 1998). The exceptions include periodic droughts and occasional disruption or contamination by floods, pathogen outbreaks, and other anthropogenic or nat- ural disasters (e.g. Yarnal et al. 1997, 1999). If climate change were to bring increased climate variation with more droughts, floods, and water-borne pathogen outbreaks, then the ability of future supply to meet future demand is uncertain. Adding to this uncertainty, the ability of future supply to meet demand is indeterminate because of the large uncertainty surrounding future demand.

\section{CLIMATE VARIATION AND WATER}

As noted, climate variation has a large effect on hydrology and, consequently, on the water available for human and ecosystem use in the M AR. This section will relate climate to streamflow, groundwater, and water quality on various temporal and spatial scales. Much of the work will use the SRB to represent region-wide processes, relationships, and trends. The SRB is the largest river basin in the region and covers $55000 \mathrm{~km}^{2}$, including all 4 physiographic regions of the MAR (Polsky et al. 2000, in this issue). The basin contributes over $60 \%$ of the freshwater input to the Chesapeake Bay (M iller 
1995), and provides $90 \%$ of the freshwater to the northern part of the bay (Schubel \& Pritchard 1986). Thus, the SRB can be considered representative of the hydrology and water resources of the broader MAR.

\subsection{Streamflow}

There is a close association between streamflow and climate in the region. Fig. 2 shows the relationship between smoothed precipitation and smoothed streamflow from the SRB for a recent $11 \mathrm{yr}$ period. The adjusted $R^{2}$ for the unsmoothed values of the entire historical record (1895 to 1997) is 28\%; the most recent $11 \mathrm{yr}$ are presented alone in Fig. 2 for clarity. Note the slight lead of precipitation ahead of streamflow. During this decade, there is an upward trend in both precipitation and streamflow. The monthly, unsmoothed curves illustrate that high streamflow results from basin-wide weather and climate events, such as the March 1993 'superstorm,' the spring melt after the record snow year of 1993-94, the J anuary 1996 flood (Yarnal et al. 1997), and the record wet year of 1996 (Yarnal et al. 1999). In contrast, drought periods, such as the 1991 and 1995 basin-wide droughts, are more difficult to discern in the monthly data, but are readily apparent in the smoothed curves.

Long-term flow in the SRB (Fig. 3) also suggests the influence of climate. For instance, the rain-on-snow flood of M arch 1936 (Lichtenwalner 1936) and the Hurricane Agnes flood of J une 1972 (Bailey et al. 1975) are evident in the unsmoothed data. Similarly, the decadelong drought of the 1960s (Cook \& J acoby 1983) and the very wet decade of the 1970s (Yarnal \& Leathers 1988) appear in the smoothed curve. Despite the record snowfalls of the 1990s and the record wet year of 1996, from this perspective the 1990s were not outstandingly wet in the SRB.

\subsection{G roundwater}

Groundwater provides $10 \%$ of the freshwater used for human activities in the MAR (Table 1). It is especially important to public, domestic, and commercial water supplies. The Pennsylvania Department of Environmental Protection uses a 49-site network of monitoring wells established and maintained by the United States Geological Survey as part of the state's drought management system (Smith 1998). Data from this network can be used to show the close association between groundwater level and climate variation.

Since these data are only available for Pennsylvania, we could not conduct our groundwater analysis for the SRB (see Fig. 1). Instead, we assigned each well to 1 of 5 precipitation-based regions (White et al. 1991; Fig. 4). Because the geology of these regions is

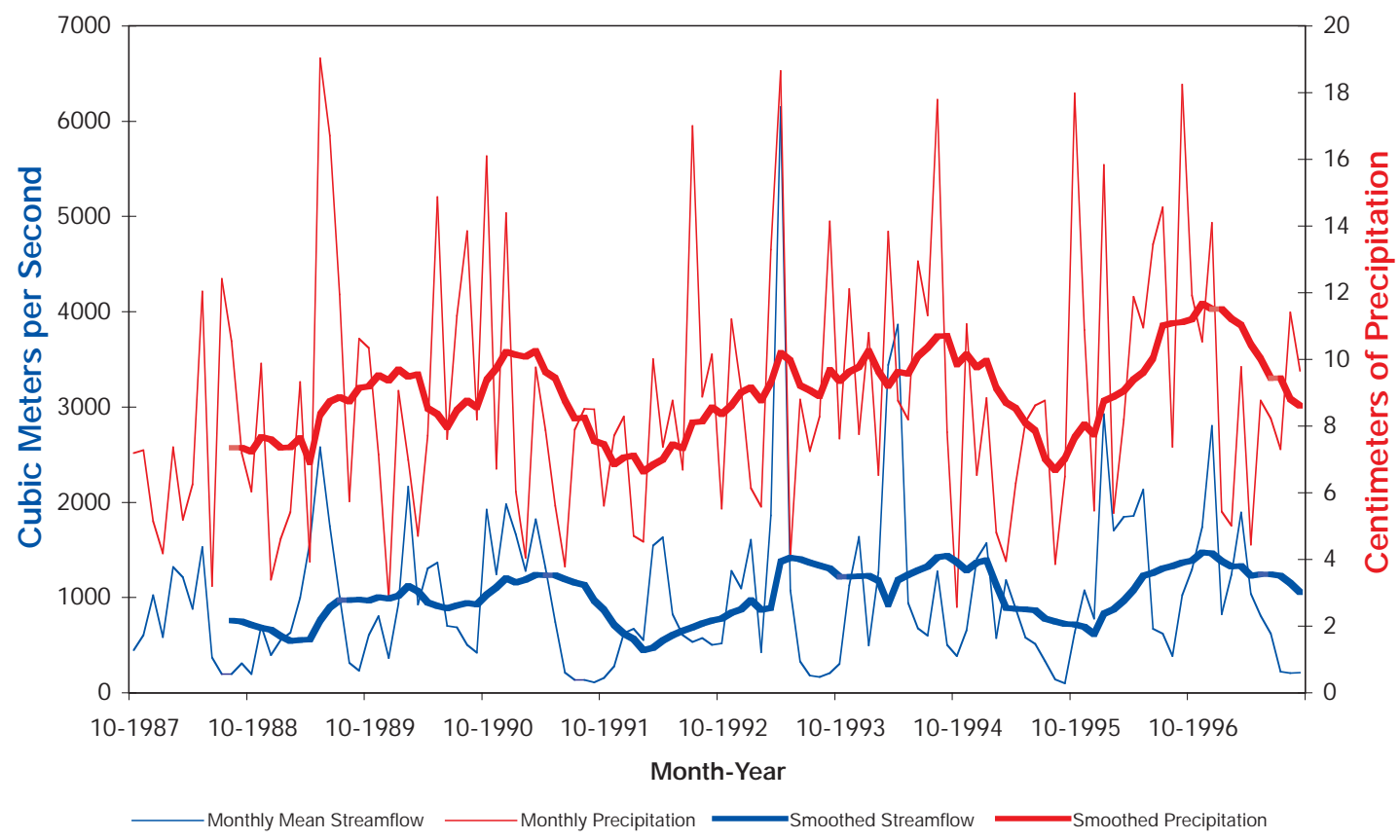

Fig. 2. Monthly streamflow for the Susquehanna River at Harrisburg, Pennsylvania, and mean monthly precipitation over the SRB, 1988 to 1997. Smoothed values use an 11 mo running mean 


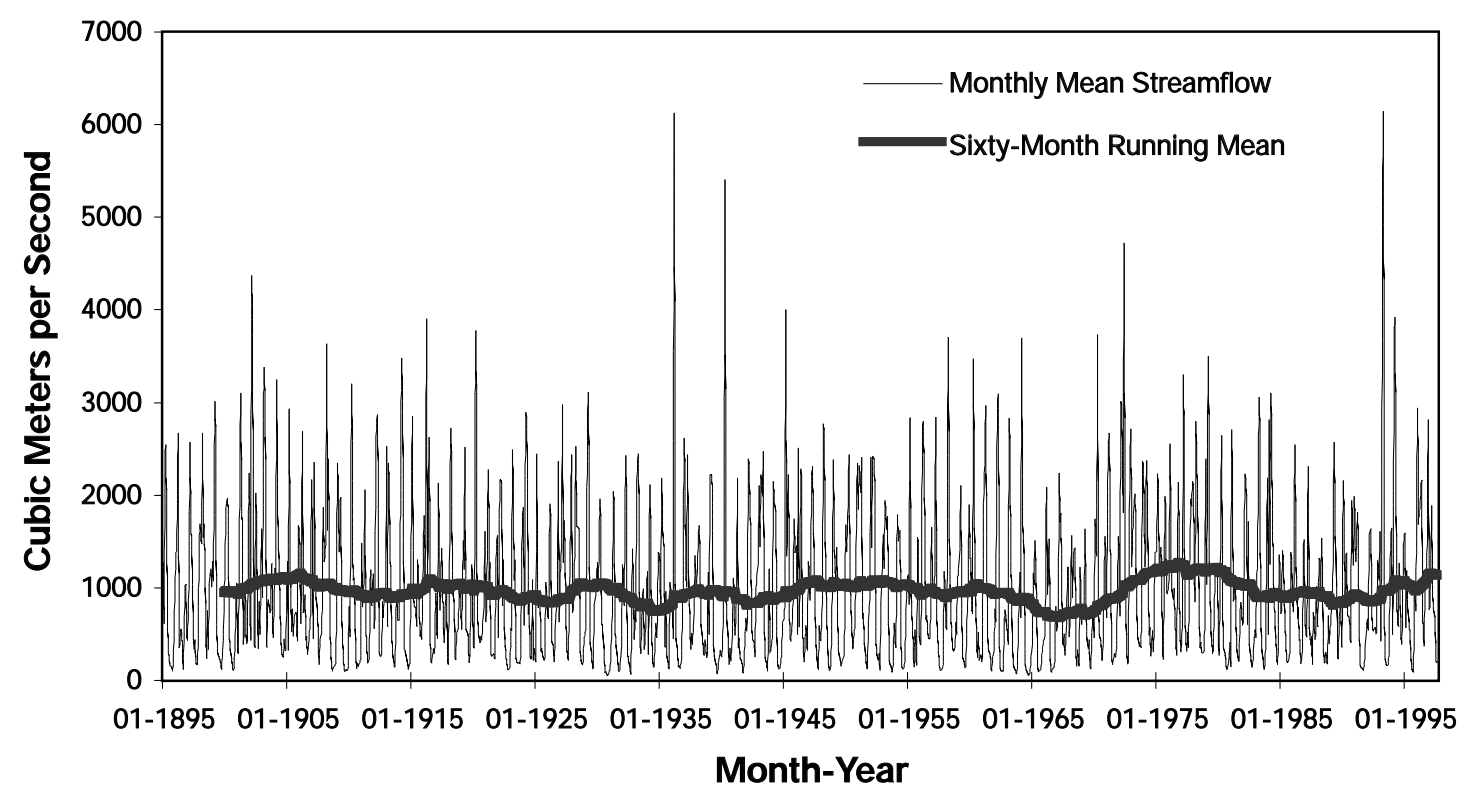

Fig. 3. Monthly Susquehanna River flow at Harrisburg, Pennsylvania, 1895 to 1997

not homogeneous, the groundwater levels for each station were normalized, thus negating the effects of geology on the mean and variance of any individual station. These normalized values were then averaged for each of the 5 regions shown in Fig. 4. The result was a time series of normalized regional mean groundwater levels. Unlike streamflow records, reliable groundwater records are only available for more recent decades. While some stations do provide records as far back as the 1940s, others only contributed data for the 1970s or later through the present. Generally, using records earlier than 1970 resulted in biased estimates of regional average groundwater levels; thus, the historical records for each region were truncated at a point in time that provided consistent estimates of regional groundwater levels before they were normalized. For northwest Pennsylvania (the analysis presented in this paper), data from 1972 through the present were used.

The next task was to relate the time series of regional average $z$-scores (variations around the mean) to historical climate data. A stepwise regression suggested a relationship between groundwater levels and precipitation as far back as an $18 \mathrm{mo} \mathrm{lag.} \mathrm{This} \mathrm{presented} \mathrm{a} \mathrm{sta-}$ tistical challenge due to multicolinearity among lagged precipitation values. To alleviate this problem, a temporal principal components analysis was performed on the precipitation data to reduce the number of lagged precipitation values to a more manageable number of principal components. These components were then regressed as independent variables against the normalized regional mean groundwater levels. Because precipitation is used as the sole factor determining groundwater levels in this model, evapotranspiration is not accounted for. However, regressions using temperature and the Palmer Drought Severity Index (PDSI; see Alley 1984) did not yield significant results, so we concluded that evapotranspiration historically has not been an important factor determining groundwater levels in northwest Pennsylvania. However, we cannot rule out the possibility that evapotranspiration may become a more important factor determining groundwater levels as temperatures and $\mathrm{CO}_{2}$ levels increase.

Using this statistical model, climate data can predict contemporary groundwater fluctuations (not shown). In the case of northwest Pennsylvania, for example, climate variations capture $68 \%$ of the variance in watertable height. This relationship also can be used to project future groundwater levels.

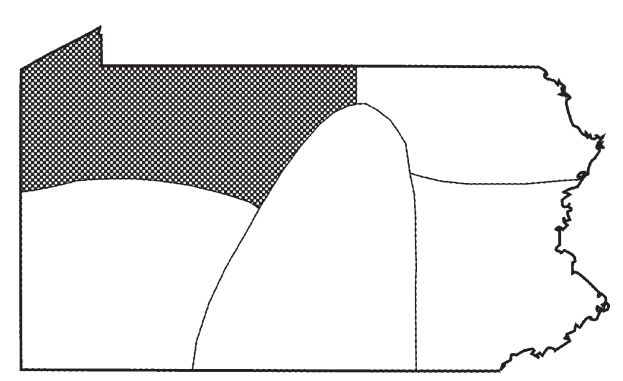

Fig. 4. Precipitation-based regions of Pennsylvania from White et al. (1991). The northwest region, for which groundwater projections are provided herein, is shaded in gray 


\subsection{Water quality}

Contemporary climate variation affects both the quantity and quality of available water resources; similarly, climate change will influence future water quality. Although climate can directly affect water quality, for instance, by increasing sedimentation or water temperature, more commonly climate exacerbates waterquality problems caused by human activity. Therefore, to understand the influence of future climate variation and change on regional water quality, it is important to understand how humans have affected MAR water quality in the past.

Before European settlement, the native peoples of the region had little impact on water resources (e.g. Cooper \& Brush 1993, Walker et al. 1999a). Early European settlers also had minimal influence, but by the late 18th century rapid population growth and associated land clearing, agriculture, and construction produced severe sedimentation in the region's water bodies. Although land clearing, agriculture, and therefore sedimentation declined rapidly after the Civil War, industrialization and strong population growth resulted in other forms of water pollution. Many of the most severe problems associated with point-source discharges into streams and rivers have been cleaned up in the last few decades. Nevertheless, since World War II, extensive development around and between urban centers, increased fertilizer use, increased intensity of animal husbandry operations, and increased atmospheric nitrogen deposition further degraded the waters of the region in many ways (Walker et al. 1999a).

For example, increased nutrient loading is associated with increased occurrence of hypoxic and anoxic conditions, excessive algal growth, blooms of undesirable algae, and declines in submerged aquatic vegetation. For phosphorus, estimated fluxes from the land, through the rivers, and into the estuaries and bays increased slowly between 1900 and 1945, then began a sharp increase that lasted until 1971. The majority of this increase was due to wastewater inputs. The Federal Water Pollution Control Act of 1972 and the Clean Water Act amendment of 1977 provided the basic legislative structures and authorities for regulating discharges of pollutants to waters of the United States. A precipitous decline in phosphorous inputs from wastewater resulted from removal of phosphorus from detergents and improvements in wastewater treatment. For nitrogen, agricultural inputs to the MAR's estuaries and bays have risen steadily since World War II. Estimated nitrogen inputs attributable to atmospheric deposition also rose steadily until 1970 (except for a slight dip in the depression years), and have fallen somewhat since then. Direct wastewater contributions of nitrogen have risen systematically throughout the century. The net effect has been a dramatic increase in the nitrogen flowing from land to coastal receiving waters.

Water quality in the regional rivers and streams, lakes, groundwater, and wetlands are documented in water-quality reports from the states as required by the Clean Water Act. These documents assess various uses including aquatic life support, swimming use support, and fish consumption. Current water-quality problems that compromise designated uses have various causes: abandoned mine drainage, agriculture, siltation, nutrients, metals pollution, organic enrichment/low dissolved oxygen, municipal point sources, and other forms of habitat alteration. Major causes of degradation vary from state to state.

For example, State of Pennsylvania (1998) indicates that $66.4 \%$ of rivers and streams support aquatic life. Acid mine drainage from coal mines accounts for the largest proportion (41\%) of assessed waters not meeting overall designated use support, while agricultural operations account for the second largest impact (30\%) of assessed waters. Pennsylvania does not have a coast and does not report impacts on estuarine water quality. Nevertheless, the SRB and Delaware River Basin drain eastern Pennsylvania, and nutrient fluxes from these watersheds affect estuarine water quality in Maryland and Delaware. State of M aryland (1998) reports that $50 \%$ of estuarine waters are considered impaired, with the principal causes being eutrophication/low oxygen, bacterial indicators, pesticides, and pathogenic algae. Similarly, State of Delaware (1998) reports that $50 \%$ of Delaware Bay supports aquatic life, but is threatened. Nutrients are a major contributor to these problems.

The major urban areas of the MAR coast have serious water-quality concerns. Drinking water is supplied from upstream rivers and reservoirs and therefore is affected by the nutrient and other water-quality problems noted above. Storm-water management in urban areas also is a major worry. As a result of these and other water-quality issues, for instance, $95.3 \%$ of the of the rivers and streams in the District of Columbia (DC) do not support use designations (DC 1998). In DC lakes, $43.1 \%$ do not meet aquatic life support criteria. The most serious estuarine problem is the accumulation of nutrients; none of the DC estuarine waters supports overall use designations.

To overcome some problems related to regional characterization of the surface water condition and to differences in reporting across state boundaries, new probability-based sampling designs are being used to obtain unbiased estimates of current conditions in the MAR streams, rivers, and estuaries (US EPA 1998, 1999). These methods show that, in general, problems associated with industrial and municipal point sources (metals, pH, biological oxygen demand) impair a much 
smaller portion of the region's surface waters than nonpoint sources of pollution and other forms of habitat alteration. Most non-point sources of excessive nutrients (nitrogen and phosphorus) to freshwater bodies in the region originate from fertilizer and manure application in widespread agricultural areas of this region, from wastes from animal husbandry operations, and from fossil fuel combustion resulting in atmospheric deposition of reactive nitrogen. Land-use changes, including elimination of wetlands and modification to riparian zones, degrade water quality by diminishing the nutrient-retentive capacities of the landscape (J ones et al. 1997). A long the M AR coast, urban centers further pollute surface waters by dumping wastewater into tidal estuaries.

Thus, these and other studies (e.g. USGS 1999) indicate that the MAR's water-pollution problems are closely related to nutrients. Nitrogen and phosphorous concentrations in streams and groundwater tend to be well above the national average. In the southeastern part of the lower SRB and the northeastern part of the Potomac River Basin, for example, many small shallow aquifers with carbonate bedrock have elevated nitrate concentrations, exceeding the EPA drinking water standard of $10 \mathrm{mg} \mathrm{l}^{-1}$. The concentration of phosphorus in the DC area also exceeds the EPA standard of $0.1 \mathrm{mg} \mathrm{I}^{-1}$. In addition, the estimated nitrogen deposition from the atmosphere is higher in the MAR than in other parts of the nation, accounting for as much as $25 \%$ of the nitrogen entering the Chesapeake Bay (Fisher \& Oppenheimer 1991).

The Susquehanna River is the largest watershed in the region and contributes most of the freshwater to the upper Chesapeake Bay north of the Potomac (Schubel \& Pritchard 1986). Although nitrate concentrations at Harrisburg are generally lower than the EPA standard, these concentrations contribute a large amount of nitrate to the bay when accompanied by high flows. In 1996, about one-half of the annual phosphorus and one-quarter of the annual nitrogen transported into the bay occurred during the J anuary Susquehanna flood (Zynjuk \& Majedi 1996). If such a flood were to occur in spring or summer under altered climate, the impacts on the bay could cause an increase of algal growth and a subsequent decrease of dissolved oxygen levels in the Chesapeake Bay. In addition, without changes in climate, future nutrient loads of the bay could be increased as the reservoirs fill with sediment, resulting in faster transport to the coast and consequently less nutrient removal (Langland \& Hainly 1997).

Thus, there are reasons to believe that with present nitrogen loads on the MAR land surface, nutrient fluxes to the coasts could increase with higher precipitation totals (Alexander et al. 1996). This hypothesis was tested by using a statistical-empirical model to estimate future water quality. Based on a $5 \mathrm{yr}$ period (1990 to 1994) of nitrate loads measured in the Susquehanna River at Harrisburg, contemporary relationships between monthly spot samples of nitrate loads and daily streamflow were calculated (Mattikalli 1996, Webb et al. 1997). Our results (not shown) verify that the nitrate loads have a strong positive relationship with corresponding streamflow $\left(R^{2}=0.8\right)$, thus suggesting that, for the purposes of this paper, nitrate loads can be estimated from streamflow projections. Changes in atmospheric deposition, agricultural practices, wastewater discharges, and urbanization could alter nutrient flux flow relationships in the future.

\section{CLIMATE CHANGE AND WATER}

The climate change scenarios provided by the Canadian Climate Centre (CGCMI) and the British Hadley Centre (HADCM2) (see Polsky et al. 2000) are used here to project future streamflow, groundwater, and water quality in the MAR. To be consistent with other regional assessments, we used two $10 \mathrm{yr}$ time slices from the model outputs (2025-2034 and 2090-2099), which were selected by the National Assessment Synthesis Team (NAST) (see Fisher et al. 2000, in this issue, for further discussion of the structure of the National Assessment process). It is important to note that despite several similarities (e.g. both models are coupled with ocean circulation models, incorporate aerosols in their formulation, and produce transient runs based on an assumed $1 \%$ annual increase in $\mathrm{CO}_{2}$ concentrations), they produce very different projections of future climate. For instance, the CCC model projects an increasingly warmer and drier climate than does the Hadley model. As we demonstrate below, this results in a range of projected hydrological conditions; thus, our results should be interpreted as plausible scenarios rather than an attempt at accurate prediction of future conditions. For a detailed description of the similarities and differences between the models used, the reader is referred to Polsky et al. (2000).

\subsection{Streamflow}

To estimate streamflow changes in response to climate change, we use the water balance model of Najjar (1999), which simulates flow at the mouth of the Susquehanna River given mean monthly air temperature and monthly precipitation total over the SRB. The model is run to steady state using the mean annual cycle for 3 periods: 1900-1987, 2025-2034, and 2090-2099. Najjar (1999) provided 

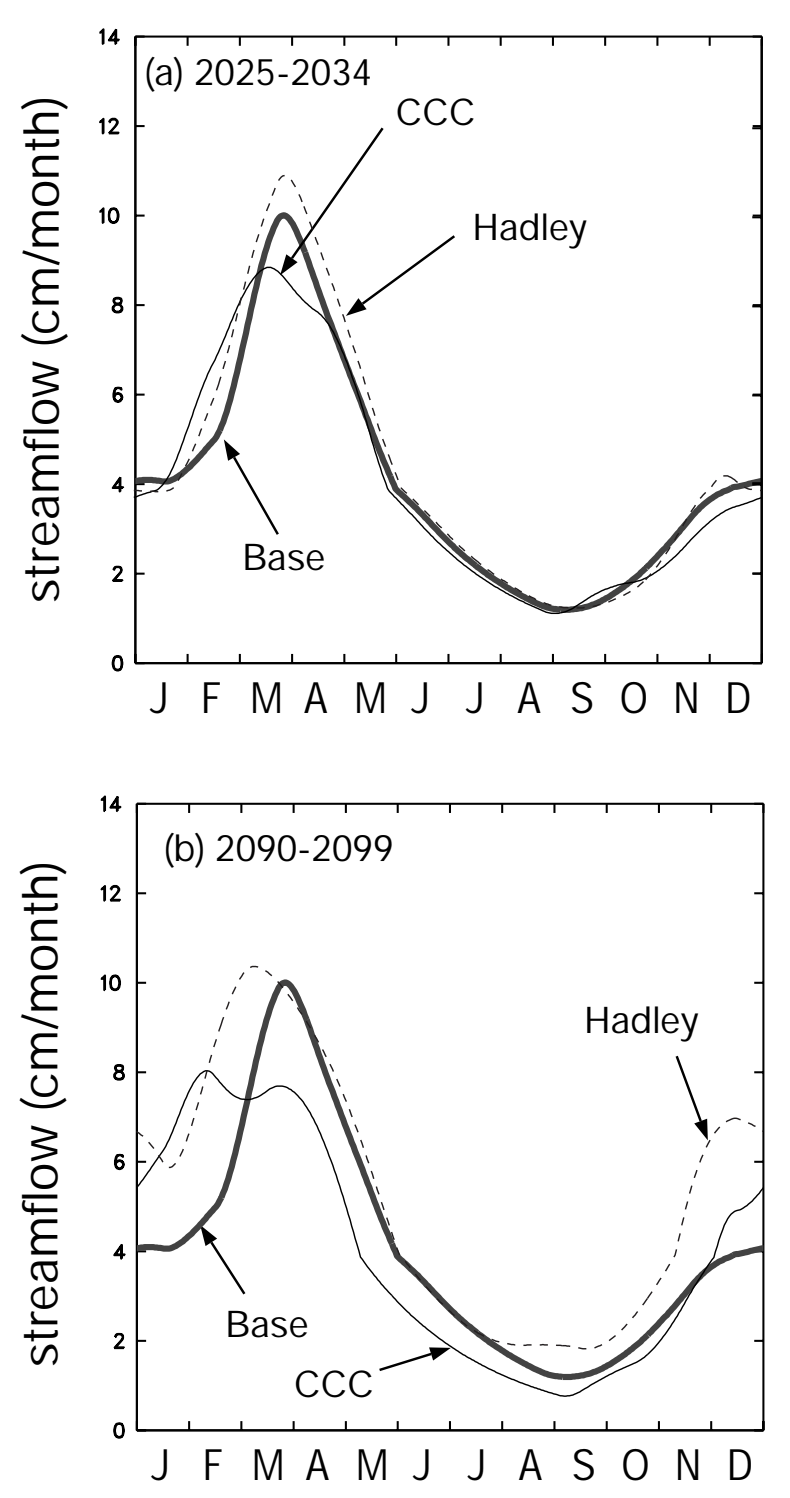

Fig. 5. Simulated flow at the mouth of the Susquehanna River for the 1985 to 1994 base period and for the Hadley and CCC models for 2 time periods: (a) 2025 to 2034 and (b) 2090 to 2099

details for the computation of the mean annual cycle in temperature and precipitation for 1900-1987. The corresponding mean annual cycle for the latter 2 periods were derived as follows. Output from the CCC and Hadley models were interpolated to a $1^{\circ}$ grid covering the SRB for the 1985-1994 base period, for 2025-2034, and for 2090-2099. Spatially averaged mean annual cycles were computed for each period and differences for temperature and precipitation were computed for the latter 2 periods with respect to the base period. These differences were added to the mean annual cycle for 1900-1987 (Polsky et al. 2000).
The simulation for $1900-1987$ captures $99 \%$ of the variability in the observed mean annual cycle (not shown). The model projects modest change in annual streamflow for 2025-2034 (Fig. 5); i.e. $+7 \%$ for the Hadley scenario and $-2 \%$ for the CCC scenario. By 2090-2099, the model projects substantially larger annual changes of $+24 \%$ for the Hadley scenario and $-4 \%$ for the CCC scenario. Although both scenarios indicate future increases in precipitation and temperature, the CCC model projects much larger temperature changes and much smaller precipitation changes than the Hadley model. Consequently, the water-balance model projects different directions in streamflow change for each scenario, both annually and for most seasons. Winter, when both scenarios suggest increased flows because of the warming-induced decreases in snow pack, is an exception. The large differences between the 2 projections highlight the difficulty of predicting future streamflow.

An important result of these projections is the shift in the seasonality of streamflow (Fig. 5). In both periods, the models accurately capture the observed double peak in streamflow. The late autumn-early winter peak comes 1 mo earlier in the Hadley scenario for 2025-2034 and the late winter-early spring peak comes 1 mo earlier in the CCC scenario for that period. Much more dramatic changes take place in 2090-2099: both peaks come 1 mo sooner in the Hadley scenario, while the CCC scenario appears to shift the early peak to a later date and the late peak to an earlier date. In all cases, these changes in the timing of average peak flows have important implications for water-resource availability and management.

\subsection{G roundwater}

To project future groundwater levels, we applied the association between contemporary water table height and climate variation to the climate change scenarios. These projections are presented for northwestern Pennsylvania (Fig. 4) in Fig. 6. This figure shows that the impact of climate change on groundwater levels depends on the climate-change scenario used. For the first sample period (2025-2034), both models project earlier seasonal recharge and drawdown of groundwater. The Hadley model projects no significant change in the annual highs and lows in water table height, while the CCC model projects less extreme annual lows and highs. This suggests that in the medium term availability of groundwater may improve in winter.

In the long term (2090-2099), the projected groundwater levels diverge. The CCC model projects even earlier seasonal recharge and drawdown of groundwater, and less interannual variation in levels; these 
results suggest greater groundwater availability in winter but less groundwater availability in summer. The Hadley model, however, now projects slightly later seasonal recharge and drawdown and, therefore, lower groundwater levels in the winter but higher levels in the summer. Thus, while these results demonstrate that climate change can be expected to affect groundwater levels, it also highlights the uncertainty inherent in projecting that impact into the distant future. Still, the results presented here suggest a possible range of impacts on groundwater levels that could be of interest to water-resource planners.

\subsection{Water quality}

Projections of future water quality in the Susquehanna River at Harrisburg are presented in Fig. 7. Under the Hadley and CCC scenarios, nitrate loads can be expected to increase in winter and late spring because of the expected increase in streamflow, especially under the Hadley model. An interesting result is that both scenarios show decreases in streamflow and associated nitrate loads in J uly and August, which could ameliorate problems associated with estuarine stratification and eutrophication in late summer. This finding is the same as the results of Moore et al. (1997) on future water quality in the M AR. However, decreases in sum-
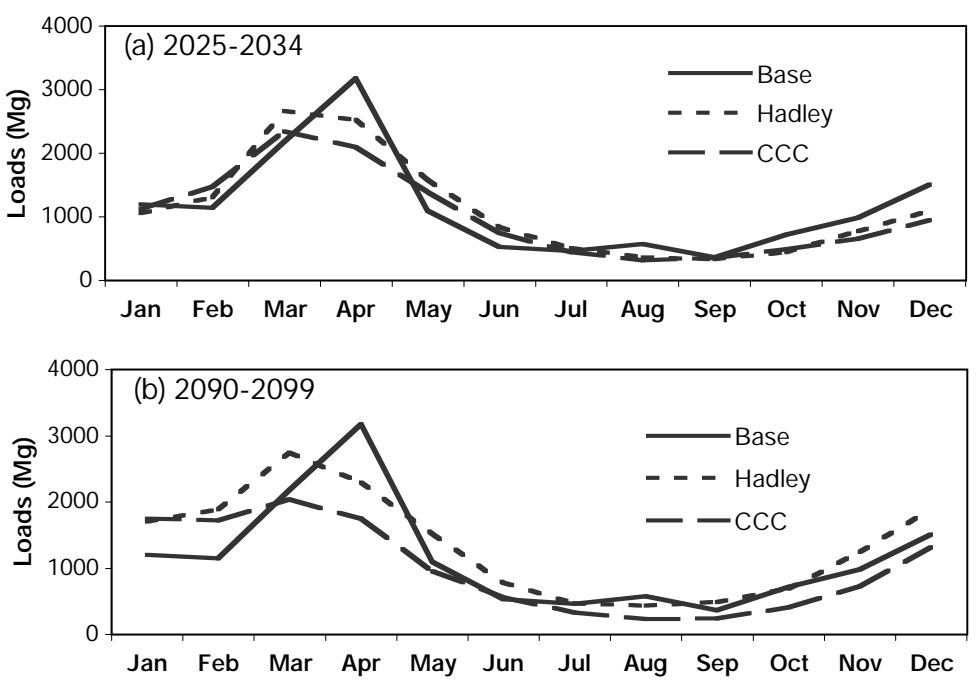

Fig. 7. Simulated nitrate loads at the Harrisburg monitoring station of the Susquehanna River for the 1980 to 1994 base period and for the Hadley and CCC models for 2 time periods: (a) 2025 to 2034 and (b) 2090 to 2099
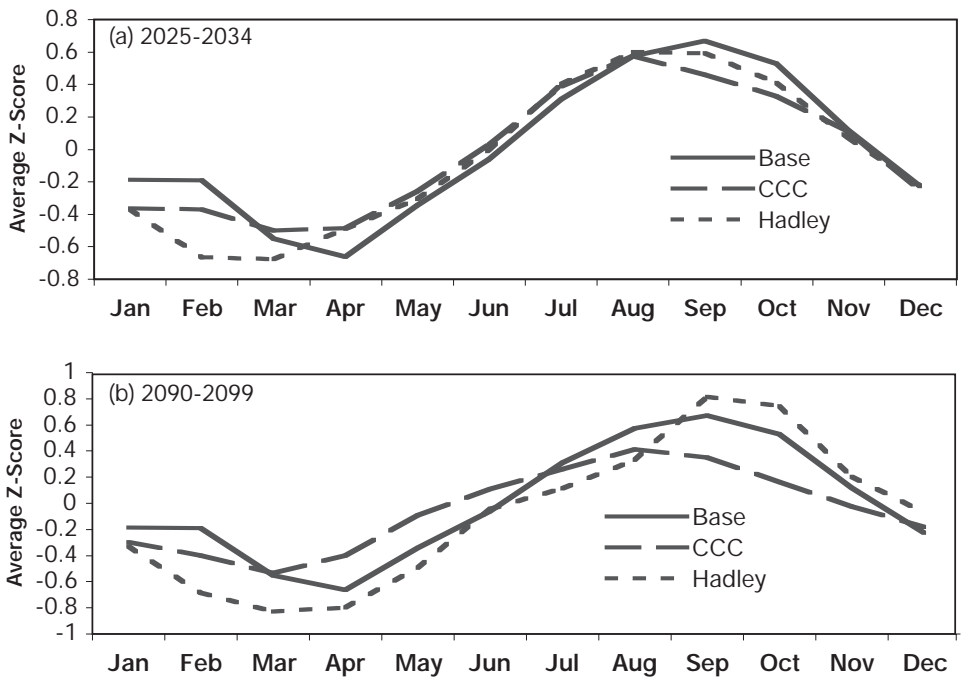

Fig. 6. Simulated groundwater levels for northwest Pennsylvania (see Fig. 4) for the historical (base) record and for the Hadley and CCC models for 2 time periods: (a) 2025 to 2034 and (b) 2090 to 2099 mer streamflow as accompanied by increases in water temperature might increase other water-quality problems such as reduced dissolved oxygen contents and increased contaminant concentration levels. In addition, it is not clear whether the human sources of nutrients and pollutants (e.g. land use, pollution policies) will continue on the same trajectories into the future. Therefore, uncertainty remains for projections of future MAR water quality.

\section{UNCERTAINTIES AND CHALLENGES OF CLIMATE VARIATION AND CHANGE}

While it would be ideal to predict the impacts of climate change on water resources accurately, no methodology can achieve that goal. Further, due to a number of confounding factors, discussed below, it is highly dubious that any method will emerge in the near future that can predict these impacts with a high level of confidence. Thus, we contend that the goal of climate change impact research should be the generation of plausible impact scenarios. That is precisely the goal of this paper. The approach taken here is to generate impact scenarios using state-of-the-art GCM runs and historical relationships between climate and the available quantity and quality of water. By using these GCM s, our impact scenarios are also directly comparable with those used 
in other regions of the United States as part of the National Assessment process. The results presented here thus provide a range of plausible impacts that could occur under a set of plausible future climatic conditions, but should not be misinterpreted as predictions. There are many feedback processes and relationships, for example, human systems involved in adaptation, which cannot be modeled deterministically over the long term.

Still, despite the uncertainty involved in projecting the impacts of climate change, our research does demonstrate that contemporary climate variation influences streamflow, groundwater, and water quality in the MAR and, consequently, the critical water resources needed by industries, municipalities, and individuals. Relationships between climate, streamflow, and groundwater are somewhat uncomplicated and reasonably well understood, but the relationship between water quality and climate is not as simple. Dry periods decrease nutrient fluxes from the land to the waters. Even modest wet periods immediately following dry periods result in the flushing of accumulated nutrients from the land and large nutrient spikes in regional waters; subsequent very wet periods may not flush as many nutrients because fewer nutrients are available. In the Piedmont and Coastal Plain provinces of the Chesapeake Bay, discharges of nitrate can be promoted by increased surface runoff and groundwater flow, but phosphorous concentrations in streams are more highly correlated with suspended solids concentrations (J ordan et al. 1997). Despite such complexities, research has demonstrated strong associations between climate variability and water quality in the M AR. For example, Walker et al. (1999b) found a chain of associations linking elements of the globalscale atmospheric circulation, MAR climate, regional streamflow, nutrient fluxes to the region's estuaries and bays, and oxygen conditions in these water bodies. Cronin and collaborators (pers. comm.) have found similar linkages among the global-scale circulation, regional climate, streamflow, and sedimentation in the Chesapeake Bay.

This study has also shown that climate change will influence streamflow, groundwater, and water quality. The 2 climate change scenarios used here both found that water quantity and quality will vary in the future with the climate. These scenarios and others (i.e. J enkins \& Barron 1997, Crane \& Hewitson 1998) suggest that the future climate may be wetter in the MAR. Other factors being equal, this finding means that streamflow and groundwater could provide more water for human and ecosystem use.

Nevertheless, other factors are not necessarily equal. Streamflow is difficult to project because of the offsetting effects of increased temperature and precipita- tion. Our results (see Fig. 5) show that the sign of the change cannot be estimated because one climate model scenario is much warmer and drier than the other. Three published studies on the streamflow response to climate change in the MAR highlight this uncertainty. All use water-balance models combined with climate model scenarios for a doubling of $\mathrm{CO}_{2}$. M cC abe \& Ayers (1989) estimated streamflow changes in the Delaware River Basin of $-36,-7$, and $+4 \%$, depending on the particular climate model used. M oore et al. (1997) calculated streamflow decreases of 21 to $31 \%$ for the Northeast United States. Najjar (1999) computed a $24 \pm 13 \%$ increase in flow at the mouth of the Susquehanna River. Yang et al. (1999), using a suite of regression-based models with doubled $\mathrm{CO}_{2}$ scenarios, found similar results for the SRB. Increased precipitation variation will likely be reflected in increased streamflow variation, making the delivery of freshwater and nutrients much more variable in the future.

Other factors not accounted for here may also affect the amount of M AR streamflow in the future. Elevated $\mathrm{CO}_{2}$ may decrease evapotranspiration on land, thereby increasing streamflow. For example, Wigley \& J ones (1985) estimated that a doubling of $\mathrm{CO}_{2}$ could increase streamflow as much as $20 \%$ for watersheds in which half of the precipitation runs off (recall that one-third of MAR precipitation contributes to groundwater and surface-water flow and is available for human use). Increased urbanization will increase the fraction of land that is impervious, resulting in increased streamflow. In their comprehensive analysis of long-term streamflow variations in the United States, DeWalle et al. (2000) saw a significant urbanization signal, suggesting that future impacts of urbanization on streamflow are likely to be as large as climate change impacts. The combined uncertainty of the effects of precipitation, temperature, $\mathrm{CO}_{2}$, and urbanization on streamflow makes projections extremely uncertain.

Similarly, recall that our groundwater model does not account for evapotranspiration. While this shortcoming does not affect the predictive power of the model when simulating historical groundwater levels, it is possible that as temperatures and $\mathrm{CO}_{2}$ levels increase in the region, evapotranspiration could become an increasingly important determinant of groundwater levels in the region. Still, our projections suggest that groundwater levels will be affected by future climate change, even if we cannot pinpoint the exact effect.

Wetter future conditions have clearer implications for the potential impacts of climate change on water quality. Walker et al. (1999) show that increased precipitation could increase nutrient fluxes to the region's rivers, estuaries, and bays. Thus, to reduce water- 
quality problems in a wetter world, it will be necessary to make policy changes that influence the human sources of the nutrients that affect the waters of the MAR, such as land-use and atmospheric deposition.

Although there are threats from non-point-source pollutants with higher runoff, the prospect of additional water resources would appear to be attractive. For example, there could be fewer occurrences of drought watches, warnings, and emergencies. However, favorable situations may not always be the case. Four examples illustrate the management challenges that could come with additional water in the context of higher temperatures. First, dam managers would have to provide for low water levels in anticipation of a longer period of high runoff at the same time that demands for a high and stable water level for freshwater recreation could increase. Second, water and sewage treatment facilities are often located in floodplains. A greater frequency of high runoff events would require protection of these facilities to avoid harmful health impacts from their failure. Third, higher rates of groundwater recharge could lead to greater frequencies of groundwater surcharge in lowlying areas of karst landscapes, as well as to failure of septic disposal systems. Finally, even with greater flow in general, there would still be seasonal and episodic occurrence of low river-flow levels, most likely during the periods of highest summer and early fall temperatures. During these periods, peak power demands for air conditioning would require greater consumptive (evaporative) water loss in cooling towers or would stimulate greater evaporation from higher stream temperatures in energy-production systems that use oncethrough cooling. Either process-diminished flows or elevated stream temperatures-would negatively affect the ability of streams to dilute and process pollutants, thus exacerbating water pollution during lowflow periods.

In sum, this work suggests that most conceivable variations and changes in climate will influence the availability and quality of water in the MAR. Although present climate models may not be able to project future climate change with accuracy or certainty, it is clear that the region's water is sensitive to climate variation. The fact that the impacts of future climate change cannot be accurately predicted should not be construed to mean that nothing can or should be done about climate change impacts on water resources. Rather, considering the rather dramatic range of projections, climate change can and should be considered a significant risk to the MAR's water resources. The sensitivities demonstrated in this paper should be a clarion call for decision-makers to insure a secure water supply in the face of a varying - and possibly changing-climate.
Acknowledgements. We would like to thank the researchers and Advisory Committee of the Mid-Atlantic Regional Assessment for their help and encouragement during the preparation of this paper. We especially want to thank J ason Allard, J ody Gibson, Brian Schorr, and Bob Swanson for their help with the data and analyses. Primary support came from the USEPA Office of Policy, Planning and Evaluation Cooperative Agreement CR-824369 and the USEPA Office of Research and Development Cooperative Agreement CR826544. Additional support was provided by the National Science Foundation Human Dimensions of Global Change Grant SBR9521952 and the USEPA Office of Research and Development Grant 824807-010. This paper is Contribution No. NHEERL-NAR-2130. Mention of trade names or commercial products does not constitute endorsement or recommendation for use by the US EPA.

\section{LITERATURE CITED}

Alexander RB, Murdoch PS, Smith RA (1996) Streamflowinduced variations in nitrate flux in tributaries to the Atlantic Coastal Zone. Biogeochemistry 33:149-177

Alley (1984) Alley W (1984) The Palmer Drought Severity Index: limitations and assumptions. J Clim Appl Meteorol 23:1100-1109

Ayers MA, Wolock DM, McCabe GJ, Hay LE, Tasker GD (1994) Sensitivity of water resources in the Delaware River Basin to climate variability and change. US Geological Survey Water-Supply Paper 2422, US Geological Survey, Reston, VA

Bailey J F, Patterson J L, Haulhus J LH (1975) Hurricane Agnes rainfall and floods, June-J uly 1972. Geological Survey Professional Paper 924, US Geological Survey and National Oceanic and Atmospheric Administration, Washington, DC

Cook ER, J acoby GC (1983) Potomac River streamflow since 1730 as reconstructed from tree rings. J Clim Appl M eteorol 22:1659-1672

Cooper SR, Brush GS (1993) A 2500-year history of anoxia and eutrophication in Chesapeake Bay. Estuaries 16:617-626

Crane RG, Hewitson BC (1998) Doubled $\mathrm{CO}_{2}$ precipitation changes for the Susquehanna basin: down-scaling from the GENESIS general circulation model. Int J Climatol 18: 65-76

DeWalle DR, Swistock BR, J ohnson TE, McGuire KJ (2000) Potential effects of urbanization on sensitivity of mean annual streamflow to climate change in the United States. Water Resour Res (in press)

DC (District of Columbia) (1998) 1998 Report to the Environmental Protection Agency and U.S. Congress Pursuant to Section 305(b) Clean Water Act (P.L. 97-117). Environmental Health Administration, Government of the District of Columbia, Washington, DC

Fisher A, Neff R, Barron EJ (2000) The Mid-Atlantic Regional Assessment: motivation and approach. Clim Res 14: 153-159

Fisher DC, Oppenheimer M (1991) Atmospheric nitrogen deposition and the Chesapeake Bay Estuary. Ambio 20: 102-108

J enkins GS, Barron EJ (1997) Global climate model and coupled regional climate model simulations over the eastern US: GENESIS and RegCM 2 simulations. Global Planet Change 15:3-32

J ones KB, Ritters KH, Wickham J D, Tankersley RD, O'N eill RV, Challoud DJ , Smith ER, Neale AC (1997) An ecological assessment of the United States M id-Atlantic Region: a 
landscape atlas. EPA-600-R-97-130. US Environmetal Protection Agency, Office of Research and Development, Washington, DC

J ordan TE, Correll DL, Weller DE (1997) Relating nutrient discharges from watersheds to land use and streamflow variability. Water Resour Res 33:2579-2590

Langland MJ, Hainl RA (1997) Changes in bottom-surface elevations in three reservoirs on the lower Susquehanna River, Pennsylvania and M aryland, following the J anuary 1996 flood - implications for nutrient and sediment loads to Chesapeake Bay. US Geological Survey, Washington, DC

Lichtenwalner NL (1936) Report of loss and damage: the March 1936 flood in Pennsylvania. State Director for the National Emergency Council, Philadelphia, PA

Lins HF, Stakhiv EZ (1998) Managing the nation's water in a changing climate. J Am Water Resour Assoc 34:1255-1264

Mattikalli NM (1996) Prediction of river discharge and surface water quality using an integrated geographical information system approach. Int J Remote Sensing 17: 683-701

McCabe GJ , Ayers MA (1989) Hydrologic effects of climate change in the Delaware River basin. Water Resour Bull 25: 1231-1242

Miller EW (1995) Water resources. In: Miller EW (ed) A geography of Pennsylvania. The Pennsylvania State University Press, University Park, PA, p 56-66

M oore MV, Pace ML, M ather J R, M urdoch PS, Howarth RW, Folt CL, Chen CY, Hemond HF, Flebbe PA, Driscoll CT (1997) Potential effects of climate change on freshwater ecosystems of the New England/Mid-Atlantic Region. Hydrol Proc 11:925-947

Najjar RG (1999) The water balance of the Susquehanna River Basin and its response to climate change. J Hydrol 219(1-2):7-19

Polsky C, Allard J, Currit N, Crane R, Yarnal B (2000) The Mid-Atlantic Region and its climate: past, present, and future. Clim Res 14:161-173

Schubel J R, Pritchard DW (1986) Responses of the upper Chesapeake Bay to variation in discharge of the Susquehana River. Estuaries 9:236-249

Smith EE (1998) An expert system approach to regional drought monitoring in Pennsylvania. MS thesis, Department of Civil and Environmental Engineering, The Pennsylvania State University, University Park, PA

Solley WB, Pierce RR, Perlman HA (1998) Estimated use of water in the US in 1995. US Geological Survey Circular 1200, US Geological Survey, Washington, DC

State of Delaware (1998) 1998 watershed assessment report (305(b)). Department of Natural Resources and Environmental Control, Dover, DE

State of M aryland (1998) 1998 M aryland Section 305(b) water quality report. Resource Assessment Service, Maryland
Department of Natural Resources, Annapolis, MD

State of Pennsylvania (1998) 1998 Pennsylvania water quality assessment. Bureau of Watershed Conservation, Pennsylvania Department of Environmental Protection, Harrisburg, PA

Steiner RC, Ehrlich NN, Boland JJ , Choudhury GS, Teitz W, McCusker S, Yamamoto A (1997) Water resources management in the Potomac River Basin under climate uncertainty. ICPRB Report 94-3, Interstate Commission on the Potomac River Basin, Rockville, MD

US EPA (1998) Condition of the Mid-Atlantic estuaries. EPA600-R-98-147, US Environmental Protection Agency, Office of Research and Development, Washington, DC

US EPA (1999) Mid Atlantic highlands: state of the streams report. EPA-620-R-99-002. US Environmental Protection Agency, Washington, DC

USGS (1999) The quality of our nation's waters-nutrients and pesticides. US Geological Survey Circular 1225, US Geological Survey, Washington, DC

Walker HA, Latimer J S, Dettmann EH (1999) Assessing the effects of natural and anthropogenic stressors in the Potomac Estuary: implications for long-term monitoring. Environ Monit Assess (in press)

Webb BW, Phillips J M, Walling DE, Littlewood IG, Watts CD, Leeks GJ L (1997) Load estimation methodologies for British rivers and their relevance to the LOIS RACS(R) programme. Sci Total Environ 194/195:379-389

White DA, Richman M, Yarnal B (1991) Climate regionalization and rotation of principal components. Int J Climatol 11:1-25

Wigley TML, J ones PD (1985) Influences of precipitation changes and direct $\mathrm{CO}_{2}$ effects on streamflow. Nature 314 : 149-152

Yang GW, Najjar RG, Evans BM, Shortle JS (1999) Climate change effects on streamflow in the Susquehanna River Basin, Pennsylvania. Department of Agricultural Economics and Rural Sociology, The Pennsylvania State University, University Park, PA

Yarnal B, Leathers DJ (1988) Relationships between interdecadal and interannual climatic variations and their effect on Pennsylvania climate. Ann Assoc Am Geogr 78: 624-641

Yarnal B, J ohnson DL, Frakes B, Bowles GI, Pascale P (1997) The flood of ' 96 in the Susquehanna River Basin. J Am Water Resour Assoc 33:1299-1312

Yarnal B, Frakes B, Bowles I, J ohnson D, Pascale P (1999) Severe convective storms, flash floods, and global warming in Pennsylvania. Weather 54:19-24

Zynjuk LD, Majedi BF (1996) J anuary 1996 floods deliver large loads of nutrients and sediment to the Chesapeake Bay. US Geological Survey Fact Sheet 140-96, US Geological Survey, Washington, DC 